\title{
Borderline Ovarian Serous Cystadenofibroma
}

National Cancer Institute

\section{Source}

National Cancer Institute. Borderline Ovarian Serous Cystadenofibroma. NCI Thesaurus.

Code C40029.

A neoplasm of low malignant potential arising from the ovary. It is characterized by the presence of cystic spaces which are lined by atypical serous epithelial cells. The surrounding ovarian stroma is fibrotic. There is no evidence of stromal invasion. 